\title{
A New Stereological Method for Determination of the Size of Spherical objects in Electron Microscopy: Its Application to Small Lymphocytes of the Mouse Thymus*
}

\author{
Kazuhiro AвE and Takashi Iтo
}

Received October 30, 1971

\begin{abstract}
Summary. Spherical objects appear as circular profiles on sections studied with the electron microscope. The three-dimensional size distribution of such objects has been derived from the distribution of profile sizes on sections. For this purpose, the profile diameters have generally been measured. However, it is proved to be more convenient and easy to obtain the size distribution of spherical objects from measurements of the profile areas rather than the diameters on sections. In this article, a new stereological method is proposed and its principle and procedure are described. In addition, the method was applied for determination of the sizes of small lymphocytes of the mouse thymus to reexamine the results reported in our previous paper (ABE and ITO, 1970).
\end{abstract}

Recently stereological analysis has been attempted for determination of the sizes of various formed elements in electron microscopy as well as in light microscopy (for reviews see, Elias, 1967; Weibel and Elias, 1967; Weibel, 1969; Elias, Hennig and SchWARTZ, 1971). In stereological microscopy three-dimensional interpretation of twodimensional images is needed. The stereological principles for morphometry in electron microscopic cytology are extensively discussed by WeIBEL (1969). For determination of the size of spherical objects the stereological methods thus far used have been based on the measurement of the diameter distribution of the sectional profiles (Bach, 1967; Baudhuin and Berthet, 1967; Elias and Hennig, 1967; Saltikov, 1967; Coupland, 1968). In practice, however, the precise measurement of the diameters is often attended by some difficulties, because the objects presumed to be spherical in biological specimens are not always found to be perfectly circular on sections. During the course of quantitative analysis of thymic small lymphocytes at the electron microscopic level it was proved that the stereological determination of the size of the spherical lymphocytes could be achieved with relative ease and convenience by measuring the sectional profile areas instead of the diameters on sections. The present paper, therefore, deals first with the stereological principle of the procedure proposed and secondly with reevaluation of our previous results concerning the size of small lymphocytes of the mouse thymus by means of this procedure.

\section{Stereological principle for determination of the size of spherical objects}

The basic problems related to the characterization of the size distribution of spherical objects on ultrathin sections was discussed in detail by WEIBEL (1969).

If spheres of a diameter $2 R$ are sectioned randomly, the sectional profiles appear as circles of varying diameter $2 r(R \geqq r)$. As shown in Figure 1 , if the profile circles

\footnotetext{
* Supported by a grant from Naito Research Foundation, Japan.
} 

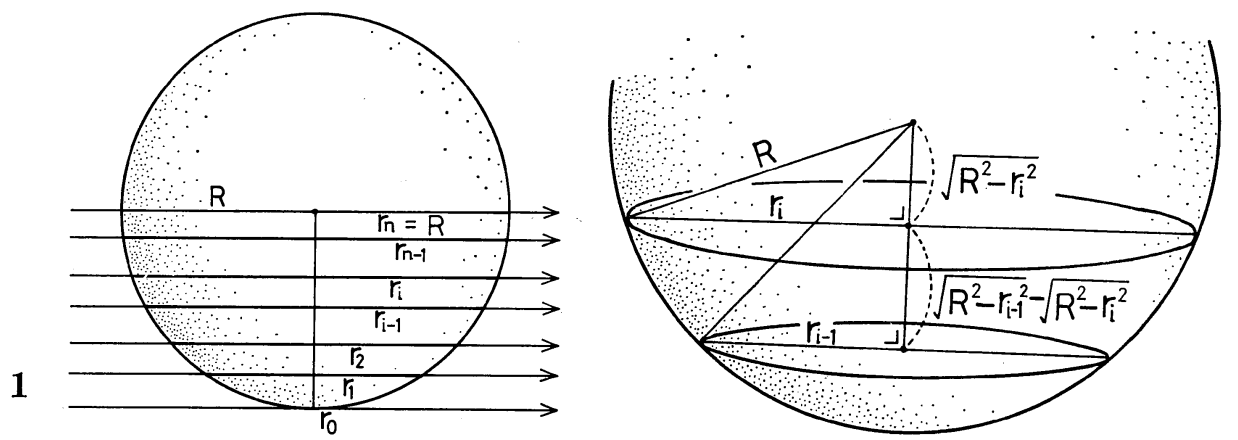

Fig. 1. The sectional circles of a sphere with a diameter $2 R$ are classified into $n$ classes of limiting ranges, $r_{0}, r_{1}, \ldots, r_{i}, \ldots, r_{n}$.

Fig. 2. Distance between two sectional circles of a sphere.

of diameter $2 r$ on sections are grouped according to the radius ranges $r_{0}$ to $r_{1}, r_{1}$ to $r_{2}$, $\ldots, r_{i-1}$ to $r_{i}, \ldots, r_{n-1}$ to $r_{n}$, the distribution frequency within each range is dependent on the distance between two sectional circles limiting each range (Fig. 2). Therefore, the frequency $F_{i}$ of sectional circles within a range between two diameters of $r_{i-1}$ and $r_{i}$ can be written as

$$
F_{i}=C\left(\sqrt{R^{2}-r_{i-1}^{2}}-\sqrt{R^{2}-r_{i}^{2}}\right)
$$

where $C$ is constant.

If the circle areas on sections are classified into $n$ classes in which the circle area of the largest limiting range is $\pi R^{2}$ and the circle area of the $i$ th limiting range is $\frac{i}{n} \pi R^{2}$ (Fig. 3), the area limiting the $i$ th range is written as

$$
\pi r_{i}^{2}=\frac{i}{n} \pi R^{2}
$$

Hence

$$
r_{i}^{2}=\frac{i}{n} R^{2}
$$

In this situation, if $r_{i}^{2}$ is substituted into equation ( 1 ), the frequency $F_{i}$ within

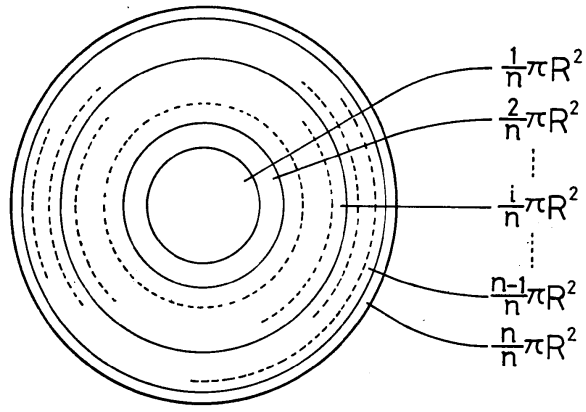

Fig. 3. The sectional areas are classified into $n$ classes according to the area in such a way that the limiting circle area of the $i$ th class is $\frac{i}{n} \pi R^{2}$. The circle area of the largest limiting range is $\pi R^{2}$, and the circle area of the smallest limiting range is $\frac{1}{n} \pi R^{2}$. the $i$ th range is expressed as

$$
\begin{aligned}
F_{i} & =C\left(\sqrt{R^{2}-\frac{i-1}{n} R^{2}}-\sqrt{R^{2}-\frac{i}{n} R^{2}}\right) \\
& =C(\sqrt{n-i+1}-\sqrt{n-i}) \frac{R}{\sqrt{n}}
\end{aligned}
$$

The frequency distribution is highest where $i=n$ between the ranges $r_{n-1}$ and $r_{n}$. The shape of the frequency distribution curve is variable depending on the value 
of $C$, although it shows a similarity.

If one gives 1 to the value of the peak, one obtains the frequency $F_{i}$ as follows:

$$
F_{n}=\frac{C R}{\sqrt{n}}=1 \longrightarrow F_{i}=\sqrt{n-i+1}-\sqrt{n-i}
$$

Thus the frequency distributions are obtained successively in turn:

$$
\begin{aligned}
& F_{n}=\sqrt{1}-\sqrt{0} \\
& F_{n-1}=\sqrt{2}-\sqrt{1} \\
& F_{n-2}=\sqrt{3}-\sqrt{2}
\end{aligned}
$$

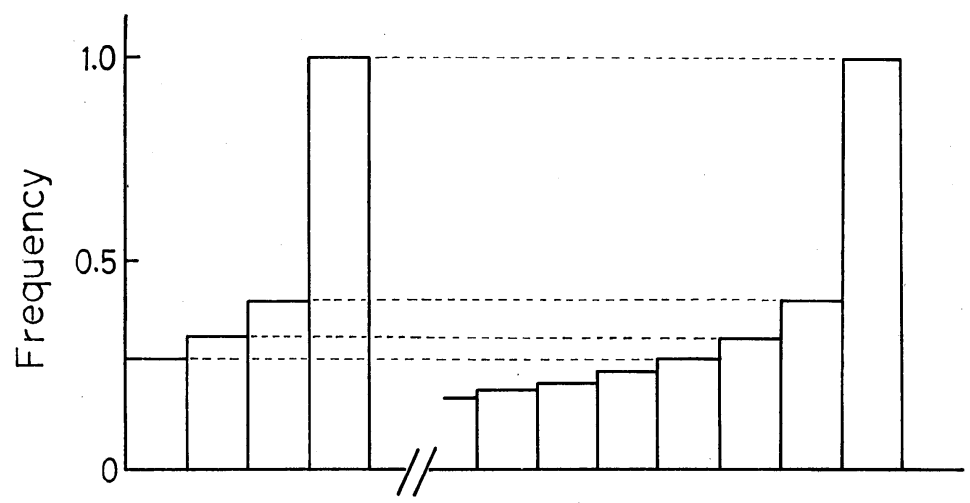

Fig. 4. The frequency distributions of circle areas on sections show a regular declination from the largest to smaller classes independently of the number of classes.

Thus the frequency distribution obtained shows a regular declination from the largest to next smaller classes independently of the number of classes (Fig. 4), and the frequency $F_{i}$ is obtained from the next formula (2), if the classes are expressed in turn from the largest to smaller classes in terms of $0,1,2,3, \ldots, i, \ldots$

$$
F_{i}=\sqrt{i+1}-\sqrt{i}
$$

When the value $A$ of the frequency at the peak is determined by actual measurement, the frequency distribution in each class can be derived directly formula (2) as follows:

$$
\begin{aligned}
& A F_{0}\left(F_{0}=1\right) \\
& A F_{1} \\
& A F_{2}
\end{aligned}
$$

If the objects comprise a mixture of two or more populations of spheres of different diameters, each population will rise to a size distribution of the profile areas. In 
this case the curve actually obtained will form a compound distribution curve, because each frequency distribution for each population is superimposed in the curve (Fig. 5).
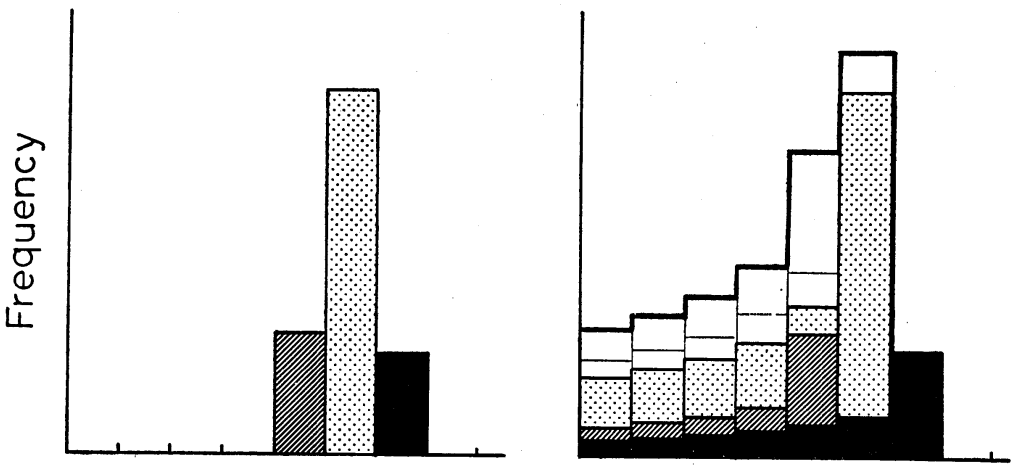

Fig. 5. If there is a mixture of three populations of spheres with different sizes (left), the size distribution of circle areas of the random sections of the spheres would represent a heavy line on the right, because three frequency distributions of sectional circles for the respective populations of spheres are superimposed.

\section{Table 1}

\begin{tabular}{ccccccccccc}
$\cdots \cdots \cdots \cdots$ & $\mathrm{A}_{10}$ & $\mathrm{~A}_{9}$ & $\mathrm{~A}_{8}$ & $\mathrm{~A}_{7}$ & $\mathrm{~A}_{6}$ & $\mathrm{~A}_{5}$ & $\mathrm{~A}_{4}$ & $\mathrm{~A}_{3}$ & $\mathrm{~A}_{2}$ & $\mathrm{~A}_{1}$ \\
\hline$\cdots \cdots \cdots$ & $\mathrm{B}_{1} \mathrm{~F}_{9}$ & $\mathrm{~B}_{1} \mathrm{~F}_{8}$ & $\mathrm{~B}_{1} \mathrm{~F}_{7}$ & $\mathrm{~B}_{1} \mathrm{~F}_{6}$ & $\mathrm{~B}_{1} \mathrm{~F}_{5}$ & $\mathrm{~B}_{1} \mathrm{~F}_{4}$ & $\mathrm{~B}_{1} \mathrm{~F}_{3}$ & $\mathrm{~B}_{1} \mathrm{~F}_{2}$ & $\mathrm{~B}_{1} \mathrm{~F}_{1}$ & $\mathrm{~B}_{1} \mathrm{~F}_{0}$ \\
$\cdots \cdots \cdots$ & $\mathrm{B}_{2} \mathrm{~F}_{8}$ & $\mathrm{~B}_{2} \mathrm{~F}_{7}$ & $\mathrm{~B}_{2} \mathrm{~F}_{6}$ & $\mathrm{~B}_{2} \mathrm{~F}_{5}$ & $\mathrm{~B}_{2} \mathrm{~F}_{4}$ & $\mathrm{~B}_{2} \mathrm{~F}_{3}$ & $\mathrm{~B}_{2} \mathrm{~F}_{2}$ & $\mathrm{~B}_{2} \mathrm{~F}_{1}$ & $\overline{\mathrm{B}_{2}}$ & \\
$\cdots \cdots \cdots$ & $\mathrm{B}_{3} \mathrm{~F}_{7}$ & $\mathrm{~B}_{3} \mathrm{~F}_{6}$ & $\mathrm{~B}_{3} \mathrm{~F}_{5}$ & $\mathrm{~B}_{3} \mathrm{~F}_{4}$ & $\mathrm{~B}_{3} \mathrm{~F}_{3}$ & $\mathrm{~B}_{3} \mathrm{~F}_{2}$ & $\mathrm{~B}_{3} \mathrm{~F}_{1}$ & $\overline{\mathrm{B}_{3}}$ & & \\
$\cdots \cdots \cdots$ & $\mathrm{B}_{4} \mathrm{~F}_{6}$ & $\mathrm{~B}_{4} \mathrm{~F}_{5}$ & $\mathrm{~B}_{4} \mathrm{~F}_{4}$ & $\mathrm{~B}_{4} \mathrm{~F}_{3}$ & $\mathrm{~B}_{4} \mathrm{~F}_{2}$ & $\mathrm{~B}_{4} \mathrm{~F}_{1}$ & $\overline{\mathrm{B}_{4}}$ & & \\
$\cdots \cdots \cdots$ & $\mathrm{B}_{5} \mathrm{~F}_{5}$ & $\mathrm{~B}_{5} \mathrm{~F}_{4}$ & $\mathrm{~B}_{5} \mathrm{~F}_{3}$ & $\mathrm{~B}_{5} \mathrm{~F}_{2}$ & $\mathrm{~B}_{5} \mathrm{~F}_{1}$ & $\overline{\mathrm{B}_{5}}$ & & & \\
$\cdots \cdots \cdots$ & $\mathrm{B}_{6} \mathrm{~F}_{4}$ & $\mathrm{~B}_{6} \mathrm{~F}_{3}$ & $\mathrm{~B}_{4} \mathrm{~F}_{2}$ & $\mathrm{~B}_{6} \mathrm{~F}_{1}$ & $\overline{\mathrm{B}_{6}}$ & & & & \\
$\cdots \cdots \cdots$ & $\mathrm{B}_{7} \mathrm{~F}_{3}$ & $\mathrm{~B}_{7} \mathrm{~F}_{2}$ & $\mathrm{~B}_{7} \mathrm{~F}_{1}$ & $\overline{\mathrm{B}_{7}}$ & & & & & \\
$\cdots \cdots \cdots$ & $\mathrm{B}_{8} \mathrm{~F}_{2}$ & $\mathrm{~B}_{8} \mathrm{~F}_{1}$ & $\overline{\mathrm{B}_{8}}$ & & & & & &
\end{tabular}

$$
F_{i}=\sqrt{i+1}-\sqrt{i} \quad F_{0}=1
$$

$$
\begin{aligned}
& \mathrm{B}_{1}=\mathrm{A}_{1}-(0) \\
& \mathrm{B}_{2}=\mathrm{A}_{2}-\left(\mathrm{B}_{1} \mathrm{~F}_{1}\right) \\
& \mathrm{B}_{3}=\mathrm{A}_{3}-\left(\mathrm{B}_{1} \mathrm{~F}_{2}+\mathrm{B}_{2} \mathrm{~F}_{1}\right) \\
& \mathrm{B}_{4}=\mathrm{A}_{4}-\left(\mathrm{B}_{1} \mathrm{~F}_{3}+\mathrm{B}_{2} \mathrm{~F}_{2}+\mathrm{B}_{3} \mathrm{~F}_{1}\right) \\
& \mathrm{B}_{5}=\mathrm{A}_{5}-\left(\mathrm{B}_{1} \mathrm{~F}_{4}+\mathrm{B}_{2} \mathrm{~F}_{3}+\mathrm{B}_{3} \mathrm{~F}_{2}+\mathrm{B}_{4} \mathrm{~F}_{1}\right) \\
& \mathrm{B}_{6}=\mathrm{A}_{6}-\left(\mathrm{B}_{1} \mathrm{~F}_{5}+\mathrm{B}_{2} \mathrm{~F}_{4}+\mathrm{B}_{3} \mathrm{~F}_{3}+\mathrm{B}_{4} \mathrm{~F}_{2}+\mathrm{B}_{5} \mathrm{~F}_{1}\right) \\
& \mathrm{B}_{6}=\mathrm{A}_{7}-\left(\mathrm{B}_{1} \mathrm{~F}_{6}+\mathrm{B}_{2} \mathrm{~F}_{5}+\mathrm{B}_{3} \mathrm{~F}_{4}+\mathrm{B}_{4} \mathrm{~F}_{3}+\mathrm{B}_{5} \mathrm{~F}_{2}+\mathrm{B}_{6} \mathrm{~F}_{1}\right)
\end{aligned}
$$


When the frequency distributions determined by measurements of the profile areas are $A_{1}, A_{2}, A_{3}, \ldots$, the three-dimensional size distributions $\left(B_{1}, B_{2}, B_{3}, \ldots\right)$ of a second sphere are successively deduced from Table 1 in the same way as done by earlier authors (Baudhuin and Berthet, 1967; Elias and Hennig, 1967; Coupland, 1968; WEIBEL, 1969).

If the largest circle area of a sphere is expressed by $S$, the diameter $(2 R)$ can be determined from

$$
2 R=2 \sqrt{\frac{S}{\pi}}
$$

The stereological method proposed is thought to be very useful to determine the size of spherical objects. The procedure may sound rather complicated, but in reality it is relatively easy and simple, if the computational procedure of this method is performed by the use of appropriate computor programs. Furthermore, even when the profiles are not perfectly circular, the measurement of the areas would be possible by means of a suitable method. When the diameters $(2 r)$ of the circles are measured, the present method would also be available if the areas of the circles are expressed in terms of $\pi r^{2}$.

\section{Application of the proposed method to the determination of the size of thymic lymphocytes}

Qualitative and quantitative electron microscopic cytology of small lymphocytes of the mouse thymus was dealt with in detail in our previous paper (ABE and ITO, 1970). In general, since small lymphocytes are assumed to be spherical in shape, our previous data on their size will be reexamined on the basis of the stereological principle proposed above.

The material was largely the same as used in our previous study, but some new material was added. The method is referred to only briefly here, because it was described in detail previously.

For electron microscopy, normal thymuses of 35-day-old dd-mice were fixed in $5 \%$ formalin in $0.1 \mathrm{M}$ phosphate buffer $(\mathrm{pH} 7.5)$ at $4^{\circ} \mathrm{C}$ for $48 \mathrm{hrs}$ and postfixed in $2 \%$ $\mathrm{OsO}_{4}$ in the same buffer for 1.5 to $2 \mathrm{hrs}$. After dehydration in the usual way they were embedded in Epon. Ultrathin sections were cut with glass knives on an LKB ultramicrotome and stained with uranyl acetate followed by lead citrate. They were examined with a Hitachi-electron microscope (HS-8). Nuclear and cytoplasmic areas of small lymphocytes in both the cortex and medulla were determined by a point counting method (WeIBEL, KISTLER and ScherLe, 1966; HeNNIG, 1967) on electron micrographs enlarged at a final magnification of 6,000 times. For the point counting a transparent plastic sheet with a regular lattice of 540 points was superimposed on the micrographs (Fig. 6), and the numbers of points lying on nuclei and cell bodies were counted. In the sheet each point was $6 \mathrm{~mm}$ from its nearest neighbors, and the points were $1 \mu$ apart when superimposed on micrographs enlarged 6,000 times. In this case, as seen in Figure 7, the area occupied by one point can be regarded as representing a hexagonal area of $\frac{\sqrt{3}}{2} \mu^{2}$. 


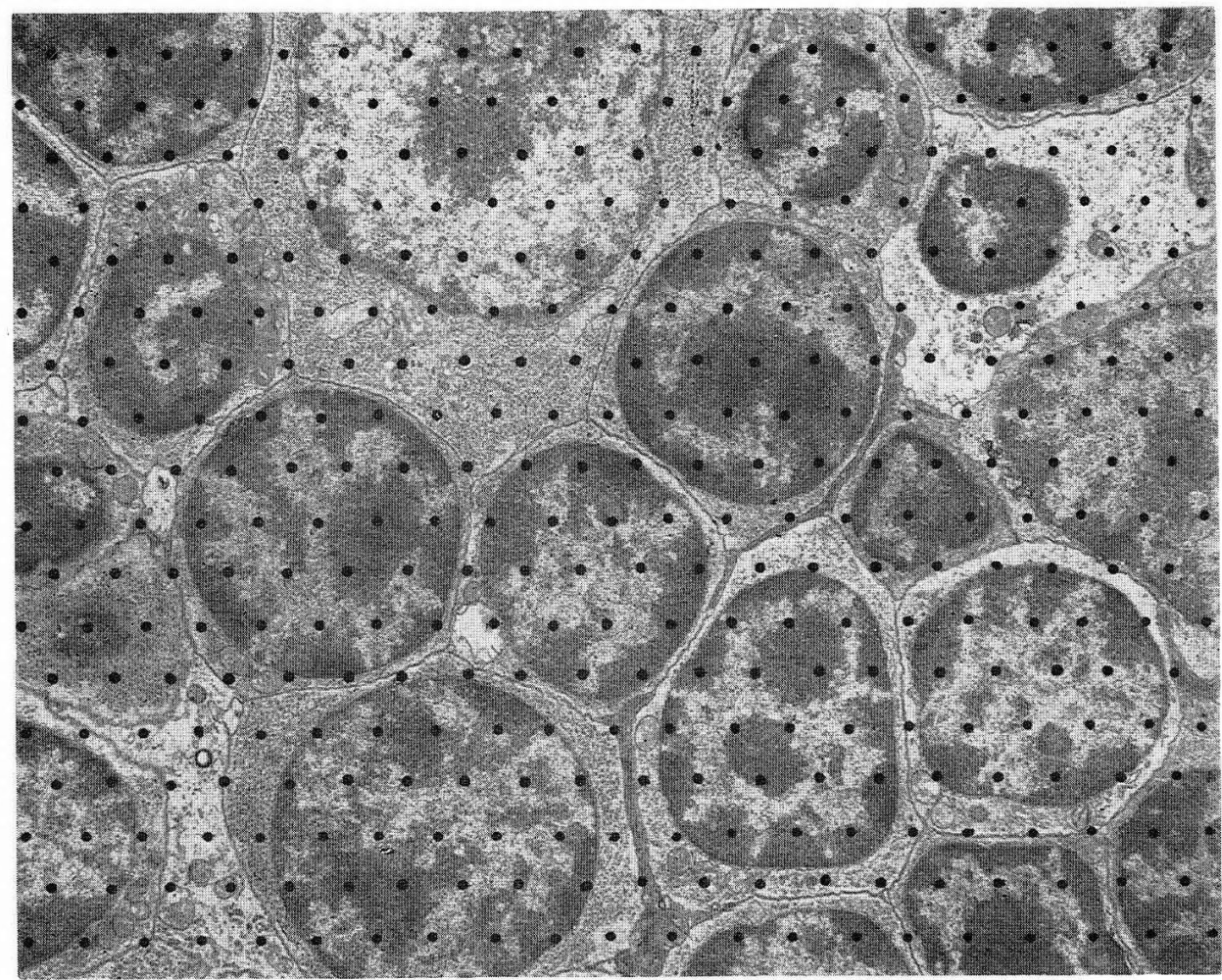

$\uparrow$

Fig. 6. A cortical portion of a thymus. The electron micrograph enlarged 6,000 times is superimposed by a regular lattice of points for measurement.

Fig. 7. One point of the lattice for measurement represents a hexagonal area of $\frac{\sqrt{3}}{2} \mu^{2}$.

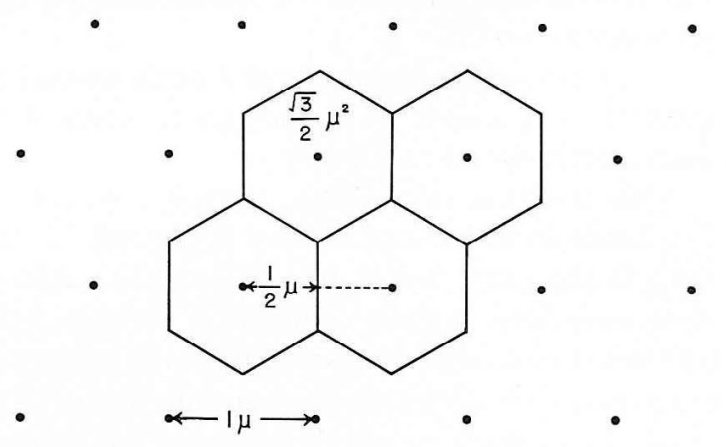

\section{a) Nucleus : cell ratio}

The nucleus : cell ratio of small lymphocytes in the cortex and medulla was obtained from the following formula by counting the numbers of test points lying on the nuclei $(\mathrm{Ni})$ and on the whole cells $(\mathrm{Ci})$.

$$
\text { Nucleus : cell ratio }=\frac{\sum N i}{\sum C i}
$$

The value obtained represents the proportion of the cell volume occupied by the nucleus. The total number of points counted was 42162 in 2459 cortical small lymphocytes and 58440 in 2328 medullary small lymphocytes, respectively. The ratio 
was 0.75 for cortical small lymphocytes and 0.55 for medullary small lymphocytes.

Evaluation of error in the point counting volumetry: The relative error in the ratio is thought to depend on the total numbers of points counted. Practically, the error would be reduced if the total number of test points counted is appropriately large. Accordingly a sampling error must be considered in the point counting volumetry. The problems of the sampling procedure were discussed in detail elsewhere (HeNnig, 1967). In this case the sampling error $(m)$ in the point counting volumetry can be obtained by the following formula:

$$
m=\sqrt{\frac{X(1-X)}{P}}
$$

where $P$ expresses the number of test points counted and $X$, the ratio. As seen from this formula, the value of $m$ represents a standard error, and the value of $X$ would fall within a range of $X \pm m$. In the case of thymic small lymphocytes, the most frequent profile of nuclei contains 20 points (Fig. 8) so that $P / 20$ or the numbers of profiles can be used instead of $P$, because in the point counting volumetry, as suggested by WEIBEL (1969), the test points should be so spaced that no more than one point would be included in the individual profile. Thus the value of $m$ is 0.01 for both cortical and medullary small lymphocytes. Therefore, the ratios are $0.75 \pm 0.01$ and $0.55 \pm 0.01$ for cortical and medullary small lymphocytes, respectively. For the two ratios, $t$ is respectively determined by the following formula.

$$
t=\frac{X_{1}-X_{2}}{\sqrt{m_{1}^{2}+m_{2}^{2}}}
$$

The ratios are statistically significant with an accuracy of $99.7 \%$ when $t>3$, and of $95 \%$ when $t>2$. In the case of thymic lymphocytes the value of $t$ is 19 , so that the ratios are statistically significant with higher confidence than $99.7 \%$.

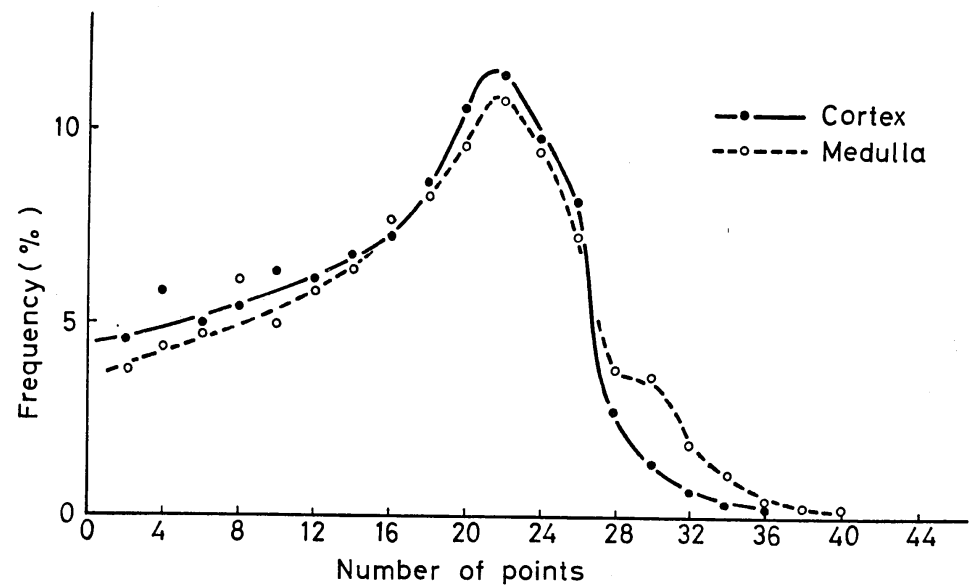

Fig. 8. The frequency distributions of areas of nuclear profiles of cortical and medullary small lymphocytes. The results were obtained from actual measurements on sections. 


\section{b) Frequency distribution of areas of nuclear and cellular profiles of thymic small lymphocytes}

The frequency distributions of areas of nuclear and cellular profiles of cortical and medullary small lymphocytes are presented in Figures 8 and 9 . The curves for the nuclei were obtained from measurements of 1247 cortical small lymphocytes and of 1249 medullary small lymphocytes, respectively. The two curves in Figure 8 are almost similar in shape and show a peak at 21 points. Since the area at the peak is $21 \times \frac{\sqrt{3}}{2} \mu^{2}$, the diameter of the nuclei most frequently encountered is calculated to be $4.9 \mu$ for both the cortical and medullary lymphocytes.

The curves of the cellular profile areas (Fig. 9) are derived from measurements of 1092 cortical small lymphocytes and 928 medullary small lymphocytes. As seen in Figure 9 , the areas of the cell profiles show different distribution patterns, and neither of the two curves has any sharp peak. However, the diameters can be obtained from

Table 2. Nuclei of cortical

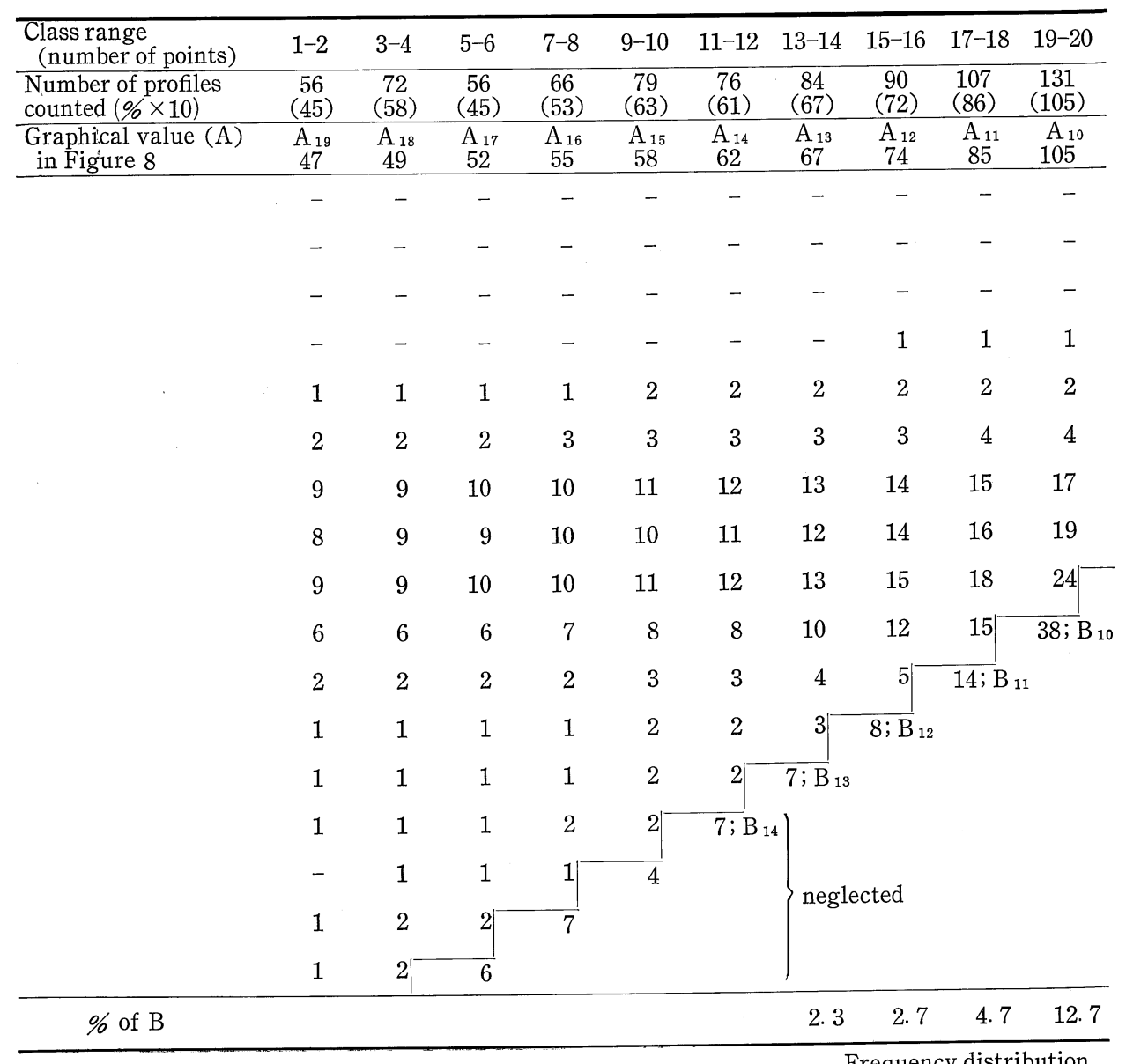




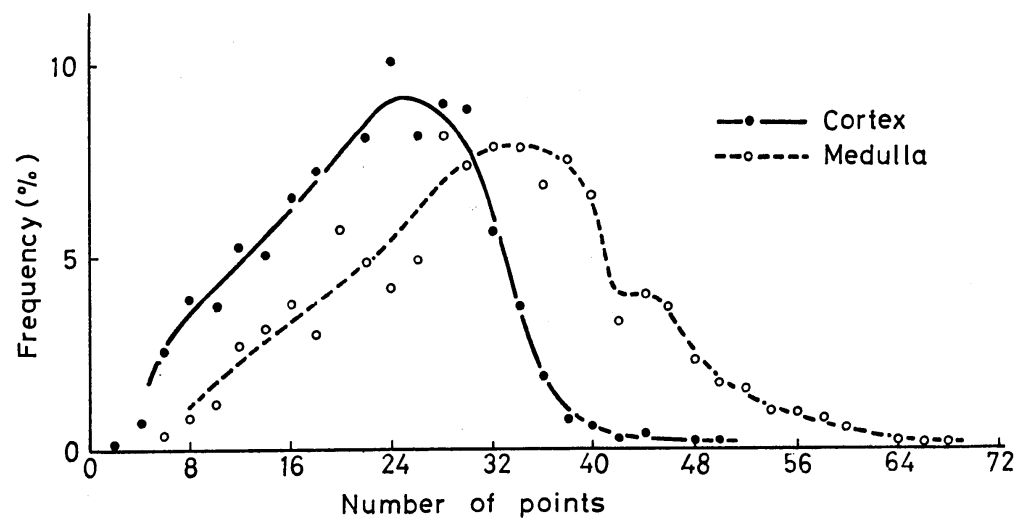

Fig. 9. The frequency distributions of areas of cellular profiles of cortical and medullary small lymphocytes. They were obtained from actual measurements. small lymphocytes

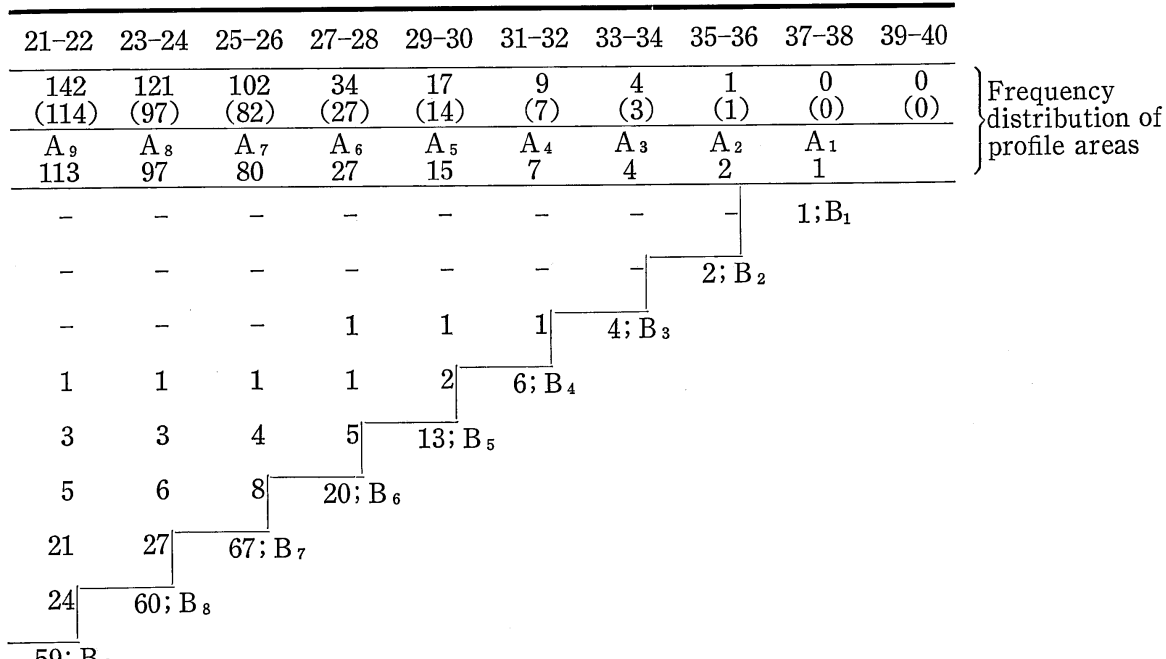

$59 ; \mathrm{B}_{9}$

$\begin{array}{lllllllll}19.7 & 20.1 & 22.4 & 6.7 & 4.3 & 2.0 & 1.3 & 0.7 & 0.3\end{array}$


the areas in which the nuclear profile areas containing 21 and 22 points are included. The cell diameter thus obtained is $5.5 \mu$ for cortical small lymphocytes and $6.4 \mu$ for medullary small lymphocytes, respectively.

It is apparent from the area distribution curves of the cell profiles that there are differences in size between cortical and medullary small lymphocytes. However, the distribution curves do not directly represent the real size distributions of small lymphocytes. If the size distributions are obtained by a stereological method, they would indicate the quantitative differences between cortical and medullary small lymphocytes more precisely.

The size distributions are obtained by means of the stereological procedure mentioned above. The data calculated for the nuclei of cortical small lymphocytes are presented in Table 2, which is made as a result of the practical application of Table 1. In this case, the value corresponding to $A$ in each class was determined from the distribution curve in Figure 8, because practically the direct value obtained from the measurements could be used if the measurements were performed in appropriate numbers of profiles. The values of $F i \times A$ may practically be omitted for the sake of simplicity in calculation if they are less than 1 , because the size distribution curve thus obtained is almost the same in shape as in the case with the real values of $F i \times A$. The negative or insignificantly small values of $B$ on the left of Table 2 are also omitted because they are presumably derived from errors.

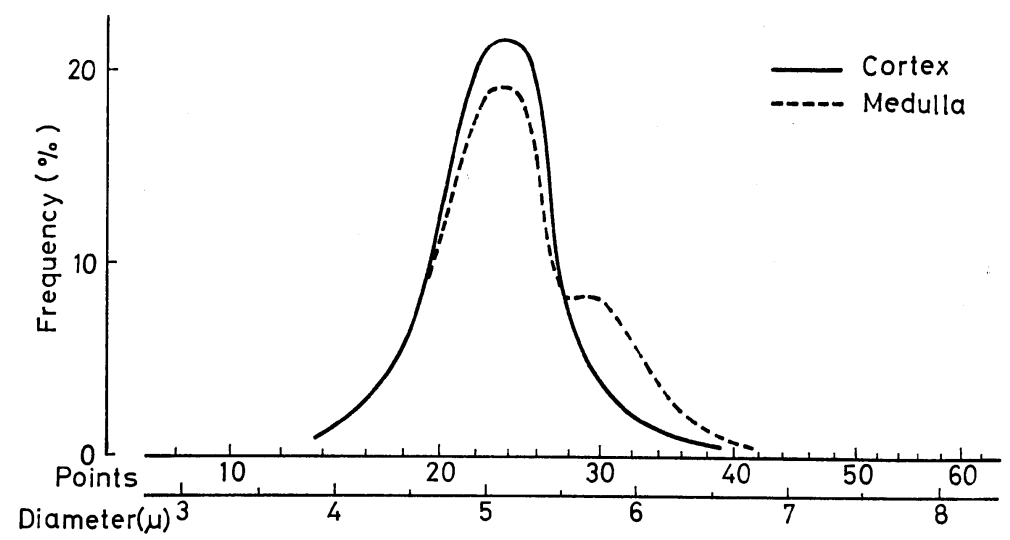

Fig. 10. The three-dimensional size distributions of nuclei of cortical and medullary small lymphocytes. They were obtained from calculations according to the stereological method proposed.

The curves of three-dimensional size distributions of thymic small lymphocytes thus obtained are presented in Figures 10 and 11.

As seen in Figure 10, the nuclear size distributions are almost the same for both cortical and medullary small lymphocytes. The nuclei of small lymphocytes are 4 to $6 \mu$ in diameter, and most of them fall within a diameter range between 4.5 and $5.5 \mu$. Relatively larger nuclei with a diameter of 5.5 to $6.0 \mu$ are slightly more numerous in medullary small lymphocytes than in cortical small lymphocytes.

The distribution of cellular sizes is significantly different in cortical small lymphocytes than in medullary small lymphocytes (Fig. 11). Cortical small lymphocytes 
have a diameter of 4.5 to $6.5 \mu$, and medullary ones, a diameter of 5.5 to $7.5 \mu$. Thus the diameters are different between cortical and medullary small lymphocytes by about $1 \mu$. The sizes of small lymphocytes most frequently encountered are calculated from the values at the peaks of the distribution curves (Table 3). From this table it may be said that the cell volume is 1.5 times greater in medullary small lymphocytes than in cortical small lymphocytes, and that the cytoplasmic volume is 2.7 times greater in medullary small lymphocytes than in cortical small lymphocytes.

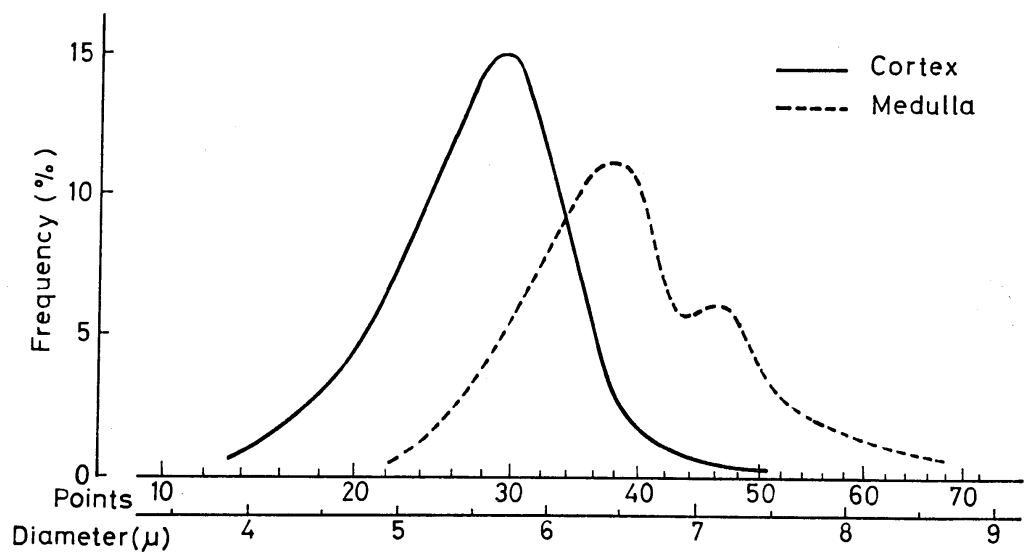

Fig. 11. The three-dimensional size distributions of cell bodies of cortical and medullary small lymphocytes. They were obtained from calculations according to the stereological method proposed.

Table 3. The sizes of thymic lymphocytes calculated from the values at the peaks of the three-dimensional size distribution curves.

\begin{tabular}{lcccccccc}
\hline & \multicolumn{2}{c}{ Diameter $(\mu)$} & & \multicolumn{3}{c}{ Volume $\left(\mu^{3}\right)$} & & Nucleus: \\
\cline { 2 - 3 } & Nucleus & Cell & & Nucleus & Cell & Cytoplasm & & cell ratio \\
\hline Cortical small lymphocyte & 5.1 & 5.7 & & 69.5 & 97.0 & 27.5 & 0.72 \\
Medullary small lymphocyte & 5.1 & 6.5 & & 69.5 & 143.8 & 74.3 & 0.48 \\
\hline
\end{tabular}

The possible functional significance of thymic small lymphocytes was discussed previously in relation to the size difference between cortical and medullary small lymphocytes (ABE and ITO, 1970). Recently at least a population of peripheral small lymphocytes is generally considered to be thymus-derived in origin. In this connection, it was suggested previously that thymus-derived lymphocytes leave the thymus as medullary small lymphocytes. In view of our previous and present results, not only qualitative but also quantitative analysis of small lymphocytes will provide a clue to the problem.

\title{
電子顕微鏡的観察における球状構造の大きさを求める新しい方法と そのマウス胸腺小リンパ球に対する応用
}

\author{
阿部和厚と伊藤隆
}

球状構造は超薄切片で円形の形象としてみとめられる. このような球状構造の立体的 
な大きさの度数分布は，切片における断面の大きさの度数分布から求めることができる. 従来 このような断面の大きさは，一般に 断面の直径の計測から求められている. しか し，断面の直径の代わりに断面積の計測によると，その処理過程が比較的便宜で容易で ある.ここではこのような新しい方法とその理論的根拠について述べ,さらにマウス 胸腺の小リンパ球の核と胞体の大きさを，この方法を応用して求め，その成績について 検討した.

\section{References}

Abe, K. and T. Ito: Fine structure of small lymphocytes in the thymus of the mouse: Qualitative and quantitative analysis by electron microscopy. Z. Zellforsch. 110: 321-335 (1970).

Bach, G.: Kugelgrössenverteilung und Verteilung der Schnittkreise; ihre wechselseitigen Beziehungen und Verfahren zur Bestimmung der einen aus der anderen. In (ed. by) E. R. Weibel and H. Elias: Quantitative methods in morphology. Berlin-Heidelberg-New York, SpringerVerlag, 1967. (p. 23-45).

Baudhuin, P. and J. Berthet: Electron microscopic examination of subcellular fractions. II. Quantitative analysis of the mitochondrial population isolated from rat liver. J. Cell Biol. 35: 631648 (1967).

Coupland, R. E.: . Determining sizes and distribution of sizes of spherical bodies such as chromaffin granules in tissue sections. Nature 217: 384-388 (1968).

Elias, H. (ed): Stereology. New York, Springer-Verlag, 1967.

Elias, H. and A. Hennig: Stereology of the human renal glomerulus. In: (ed. by) E. R. Weibel and H. Elias: Quantitative methods in morphology. Berlin-Heidelberg-New York, Springer-Verlag, 1967. (p. 130-166).

Elias, H., A. Hennig and D. E. Schwartz: Stereology: Applications to biomedical research. Physiol. Rev. 51: 158-200 (1971).

Hennig, A.: Fehlerbetrachtung zur Volumenbestimmung aus der Integration ebener Schnitte. In: (ed. by) E. R. Weibel and H. Elias: Quantitative methods in morphology. Berlin-HeidelbergNew York, Springer-Verlag, 1967. (p. 99-129).

Saltikov, S. A.: The determination of the size distribution of particles in an opaque material from a measurement of the size distribution of their sections. In: (ed. by) H. Elias: Stereology. New York, Springer-Verlag, 1967. (p. 163-173).

Weibel, E. R.: Stereological principles for morphometry in electron microscopic cytology. Int. Rev. Cytol. 26: 235-302 (1969).

Weibel, E. R. and H. Elias (eds): Quantitative methods in morphology. Berlin-Heidelberg-New York, Springer-Verlag, 1967.

Weibel, E. R., G. S. Kistler and W. R. Scherle: Practical stereological methods for morphometric cytology. J. Cell Biol. 30: 23-38 (1966).

阿部和厚

T060 札幌市北15条西 7 丁目

北海道大学医学部

解剖学第 3 講座
Dr. Kazuhiro AвE

Department of Anatomy

Hokkaido University School of Medicine

Sapporo, 060 Japan 